\title{
Pengaruh Pengaturan Waktu Pemberian Air Minum yang Berbeda Temperatur terhadap Performan Ayam Petelur Periode Grower
}

\author{
Dede Risnajati \\ Jurusan Produksi Ternak Fakultas Pertanian Universitas Bandung Raya \\ Jl. Banten No. 11, Bandung 40272
}

\begin{abstract}
ABSTRAK
Tujuan penelitian ini adalah untuk mengetahui pengaruh interaksi antara waktu pemberian air minum dan temperatur air minum terhadap performan ayam petelur periode grower. Penelitian menggunakan Rancangan Acak Lengkap (RAL) pola faktorial dengan 2 faktor perlakuan. Faktor pertama terdiri atas 5 perlakuan pengaturan waktu pemberian minum yaitu tanpa pembatasan waktu pemberian air minum (WO), pengurangan waktu pemberian air minum 2 jam (W1), 3 jam (W2), 4 jam (W3), dan 5 jam per hari (W4). Faktor kedua terdiri atas 2 perlakuan temperatur air minum, yaitu temperatur air minum $25-27^{\circ} \mathrm{C}$ (T0) dan 21 $23^{\circ} \mathrm{C}$ (T1). Setiap perlakuan diulang sebanyak 3 kali dan setiap ulangan terdiri atas 5 ekor ayam. Data dianalisis dengan sidik ragam dan uji Duncan's. Terdapat interaksi antara pengaturan waktu pemberian dengan temperatur air minum yang berbeda terhadap bobot badan dan konversi ransum. Perlakuan pengurangan waktu pemberian air minum 2 jam per hari dengan temperatur air $21-23^{\circ} \mathrm{C}$ menghasilkan performan paling baik pada ayam petelur periode grower.
\end{abstract}

Kata kunci : ayam petelur, performan, grower, air minum

\section{The Effect of Drinking Water Provision and Different Temperatures on Performance of Growing Period Laying Hens}

\begin{abstract}
The purpose of this study was to investigate the effect of interaction between drinking water provision and drinking water temperature on performance of growing period laying hens. The research used Complete Randomized Design factorial pattern with two factors. The first factor consisted of five times of drinking water provision, ie, without restriction (WO), reduction in the provision of drinking water 2 hours (W1), 3 hours (W2), 4 hours (W3), and 5 hours per day (W4). The second factor consisted of two drinking water temperatures: 25-27 ${ }^{\circ} \mathrm{C}$ (T0) and $21-23{ }^{\circ} \mathrm{C}$ (T1). Each treatment was repeated 3 times and each replication consisted of five chickens. Data were analyzed with analysis of variance and continued with Duncan's test. There was interaction between drinking water provision and drinking water temperature on body weight and feed conversion. The 2-hour reduction of drinking water provision per day with water temperature $21-23{ }^{\circ} \mathrm{C}$ produced the best performance of laying hens in growing period.
\end{abstract}

Key words: laying hens, performance, grower, drinking water 


\section{PENDAHULUAN}

Ayam memperoleh air dari 3 sumber yaitu air minum, air dari bahan makanan, dan air dari hasil oksidasi karbohidrat, lemak, dan protein. Ransum komersial unggas mengandung air lebih kurang $10 \%$, jadi kebutuhan air bagi ayam sebagian besar berasal dari air minum. Konsumsi air pada ayam petelur umumnya dipengaruhi oleh umur, temperatur lingkungan, produksi, konsumsi ransum dan kesehatan ayam (Anggorodi, 1985; Swick, 1999).

Air minum yang diberikan pada ayam harus cukup serta baik kualitasnya. Kualitas air dipengaruhi oleh adanya bakteri Eschericia coli, pH air, kadar magnesium, kadar nitrat dan nitrit, kadar sodium/klorida, serta mineral lainnya. Air minum yang bersih dan dingin adalah baik bila diberikan pada ayam terutama saat waktu udara panas karena ayam memerlukan persediaan air yang bersih dan dingin secara tetap untuk pertumbuhan optimum, produksi, dan efisiensi penggunaan ransum (Anggorodi, 1985). Dalam kondisi seperti ini, diperlukan air minum dalam jumlah yang cukup agar produksi dan pertumbuhan optimum tetap tercapai. Salah satu cara untuk mencapai kondisi tersebut adalah dengan pengaturan waktu pemberian air minum. Sehubungan dengan hal tersebut di atas, penulis tertarik untuk mengadakan penelitian dengan judul pengaruh pengaturan waktu pemberian air minum yang berbeda temperatur terhadap performan ayam petelur periode grower.

\section{MATERI DAN METODA}

Materi yang digunakan adalah ayam petelur tipe medium strain Isa Brown berumur 5 minggu sebanyak 150 ekor, ransum jenis S-21 berbentuk crumble, kandang tipe koloni dengan ukuran $23 \mathrm{~m}^{2}$ dan dibuat menjadi 30 petak dengan ukuran $80 \mathrm{~cm}$ x $80 \mathrm{~cm}$, alas kandang dialasi sekam setebal $5 \mathrm{~cm}$.

Metode penelitian adalah eksperimen dan rancangan yang digunakan adalah rancangan acak lengkap pola faktorial 5 x 2 yaitu kombinasi 5 perlakuan pengaturan air minum dengan 2 perlakuan temperatur air minum. Setiap perlakuan terdiri dari 3 ulangan dan setiap ulangan terdiri dari 5 ekor ayam. Peubah yang diamati meliputi konsumsi air minum (ml/ekor), konsumsi ransum (gram/ekor), pertambahan berat badan (gram/ekor), konversi ransum.

\section{HASIL DAN PEMBAHASAN}

\section{Pengaruh Perlakuan terhadap Konsumsi Air Minum}

Pengaruh perlakuan terhadap konsumsi air minum selama percobaan disajikan pada Tabel 1.

Pada Tabel 1 terlihat bahwa konsumsi air minum temperatur $25^{\circ}-27^{\circ} \mathrm{C}$ (T0) lebih besar dibandingkan dengan konsumsi air minum temperatur $21^{\circ}-23^{\circ} \mathrm{C}$ (T1). Konsumsi air minum pada pengurangan waktu pemberian 3 jam (W2) adalah yang terbesar dibandingkan dengan konsumsi air minum W0;W1;W2;W3;W4, dan pengurangan waktu 4 jam (W3) menghasilkan konsumsi air minum yang paling rendah. Hasil analisis ragam pengaruh perlakuan terhadap konsumsi air minum menunjukkan bahwa pengurangan waktu pemberian (W) tidak nyata pengaruhnya ( $\mathrm{P}>0.05)$ terhadap konsumsi air minum. Pengaruh tidak nyata $(\mathrm{P}>0.05)$ juga terlihat pada perbedaan temperatur air. Hasil analisis juga menunjukkan tidak terdapat interaksi pengaruh antara pengurangan waktu pemberian dan temperatur air terhadap konsumsi air minum maka tidak dilakukan uji Duncan. Konsumsi air minum dengan temperatur yang lebih dingin, lebih rendah dengan konsumsi air minum dengan temperatur yang lebih tinggi (Anonimous, 1993). Konsumsi air minum temperatur $21^{\circ}$ $23^{\circ} \mathrm{C}$ lebih rendah $4 \%$ dibandingkan dengan temperatur $25^{\circ}-27^{\circ} \mathrm{C}$. Konsumsi air minum selama percobaan adalah $109 \mathrm{ml} / \mathrm{ekor} / \mathrm{hari}$. Jumlah ini lebih tinggi $24 \%$ dari standar konsumsi air minum Isa Brown yaitu 89,8 $\mathrm{ml} / \mathrm{ekor} / \mathrm{hari}$. Hal ini disebabkan adanya 
Tabel 1. Konsumsi air minum (ml) selama percobaan pada perlakuan pengurangan waktu pemberian dan perbedaan temperatur air minum

\begin{tabular}{lcccccc}
\hline \hline Faktor & \multicolumn{5}{c}{ Faktor waktu } & Rata-rata \\
\cline { 2 - 6 } Temperatur & W0 & W1 & W2 & W3 & W4 & \\
\hline T0 & 51,80 & 56,80 & 61,00 & 53,70 & 55,00 & 55,66 \\
T1 & 55,70 & 55,10 & 51,70 & 51,10 & 53,00 & 53,34 \\
\hline Rata-rata & 53,75 & 55,95 & 56,35 & 52,40 & 54,05 & \\
\hline
\end{tabular}

temperatur udara. Standar konsumsi air minum pada Isa Brown adalah pada temperatur udara $20^{\circ} \mathrm{C}$. Konsumsi air minum pada penelitian ini juga sejalan dengan pendapat Wahju (1985) dan Swick (1999), bahwa konsumsi air minum pada periode pertumbuhan adalah 2 kali konsumsi ransum.

\section{Pengaruh Perlakuan terhadap Konsumsi Ransum}

Pengaruh perlakuan terhadap konsumsi ransum selama percobaan disajikan pada Tabel 2.

Konsumsi ransum temperatur T0, sedikit lebih besar dibandingkan dengan konsumsi ransum temperatur T1. Konsumsi ransum pada pengurangan waktu W4 adalah yang tertinggi, sedang konsumsi ransum terendah yaitu pada perlakuan W3, namun perbedaan antara konsumsi ransum tertinggi dan terendah hanya 175 gram. Hasil analisis ragam pengaruh perlakuan terhadap konsumsi ransum menunjukkan bahwa perlakuan waktu berpengaruh tidak nyata $(\mathrm{P}>0,05)$ terhadap konsumsi ransum. Perbedaan temperatur air juga berpengaruh tidak nyata terhadap konsumsi ransum. Interaksi diantara keduanya juga tidak terjadi sehingga tidak dilanjutkan dengan uji Duncan.

Konsumsi ransum selama percobaan adalah 67,5 gram/ekor/hari, relatif sama dengan standar konsumsi ransum Isa Brown, yaitu 48,4 gram/ekor/hari. Kondisi kandang yang baik, kualitas ransum, dan kondisi kesehatan ayam selama percobaan adalah faktor - faktor yang menunjang tercapainya standar konsumsi ransum tersebut. Hasil percobaan ini sejalan dengan pendapat beberapa ahli, bahwa konsumsi ransum pada ayam terutama dipengaruhi oleh temperatur lingkungan, tingkat energi metabolis ransum, berat badan, palabilitas, tingkat produksi, kualitas ransum, dan kecepatan pertumbuhan (Card dan Nesheim, 1979; Cresswel, 1977; Anonimous, 2002; Wahju, 1985) sehingga perlakuan tidak mempengaruhi konsumsi ransum. Hal ini terutama disebabkan oleh temperatur di dalam kandang yang relatif nyaman dengn kelembapan udara yang optimum sirkulasi udara di dalam kandang cukup baik karena dinding kandang menggunakan kawat harmoni yang memugkinkan aliran udara menyebar dengan baik ke seluruh bagian kandang. Atap kandang dengan monitor serta lokasi kandang yang berada di daerah perbukitan yang ditumbuhi pohon pinus menyebabkan udara yang masuk ke dalam kandang terasa segar.

\section{Pengaruh Perlakuan terhadap Pertambahan Bobot Badan}

Pengaruh perlakuan terhadap pertambahan bobot badan disajikan pada Tabel 3.

Rataan pertambahan berat badan yang dicapai pada perlakuan temperatur T1, lebih besar dibandingkan dengan perlakuan T0. Pada pengaruh perlakuan waktu menunjukkan, rataan pertambahan berat badan tertinggi, dicapai pada perlakuan W1, dan yang terendah adalah perlakuan W4. Hasil analisis ragam pengaruh perlakuan terhadap pertambahan berat badan memperlihatkan bahwa perlakuan waktu berpengaruh nyata $(\mathrm{P}<0,05)$ dari perlakuan 
Tabel 2. Konsumsi ransum (g/hari) selama percobaan pada perlakuan pengurangan waktu pemberian dan perbedaan temperatur air minum

\begin{tabular}{lcccccc}
\hline \hline Faktor & \multicolumn{5}{c}{ Faktor waktu } & Rata-rata \\
\cline { 2 - 5 } Temperatur & W0 & W1 & W2 & W3 & W4 & \\
\hline T0 & 25,00 & 24,88 & 25,05 & 24,80 & 25,09 & 24,96 \\
T1 & 24,87 & 25,01 & 24,80 & 24,95 & 24,95 & 24,92 \\
\hline Rata-rata & 24,94 & 24,95 & 24,93 & 24,88 & 25,05 & \\
\hline
\end{tabular}

Tabel 3. Rataan pertambahan berat badan (g) selama percobaan pada perlakuan pengurangan waktu pemberian dan perbedaan temperatur

\begin{tabular}{|c|c|c|c|c|c|c|}
\hline Faktor & & & aktor wak & & & $\begin{array}{c}\text { Rata-rata } \\
\text { Rata }\end{array}$ \\
\hline Temperatur & W0 & W1 & W2 & W3 & W4 & \\
\hline T0 & $530,00^{b}$ & $516,67^{b}$ & $511,67^{b}$ & $513,33^{b}$ & $488,33^{\mathrm{a}}$ & 512,00 \\
\hline $\mathrm{T} 1$ & $518,33^{\mathrm{a}}$ & $550,00^{b}$ & $538,33^{\mathrm{ab}}$ & $528,33^{b}$ & $516,67^{\mathrm{ab}}$ & 530,33 \\
\hline Rata-rata & 524,16 & 533,33 & 525,00 & 520,83 & 502,50 & \\
\hline
\end{tabular}

perbedaan air minum. Pengaruh interaksi kedua perlakuan, nyata $(\mathrm{P}<0,05)$ terhadap pertambahan berat badan. Rataan pertambahan berat badan yang dicapai pada perlakuan W4T0 nyata $(\mathrm{P}<0,05)$ lebih rendah dibandingkan dengan 4 perlakuan lainnya, dan rataan pertambahan berat badan diantaranya W0T0; W1T0; W2T0; dan W3T0 tidak nyata perbedaannya $(\mathrm{P}>0,05)$. Antara perlakuan W0T1 dan W4T1, rataan pertambahan berat badan yang dicapai, perbedaannya tidak nyata, namun nyata $(\mathrm{P}<0,05)$ lebih rendah dibandingkan W1T1. Perlakuan W2T1, rataan berat badan yang dicapai tidak nyata $(\mathrm{P}>0,05)$ perbedaannya dengan rataan pertambahan berat badan pada perlakuan W1T1; W3T1; W4T1.

Pengurangan waktu pemberian air minum 5 jam/hari dengan temperatur air minum $25^{\circ}-27^{\circ} \mathrm{C}$ (W4T0) menunjukkan hasil yang kurang baik. Hal ini menyebabkan ayam berada dalam kondisi cekaman haus. Pengurangan waktu pemberian air minum lebih dari $20 \%$ (5 jam/hari), walaupun dilakukan secara bertahap dapat menyebabkan penurunan produktivitas dan pertumbuhan (Patrick dan Schaible, 1980).

Pengurangan waktu pemberian air minum 2 jam/hari dengan temperatur air minum $21^{\circ}-23^{\circ} \mathrm{C}$ W1T1 menunjukkan hasil terbaik karena mengurangi cekaman haus yang disebabkan oleh pengurangan waktu pemberian air minum.

Temperatur air minum yang dingin menghasilkan rataan pertambahan berat badan yang lebih tinggi yaitu 530,33 g. Temperatur air yang dingin berpengaruh terhadap pertambahan berat badan karena ayam membutuhkan temperatur air dingin untuk pertumbuhan optimum (Anggorodi, 1985)

\section{Pengaruh Perlakuan terhadap Konversi Ransum}

Pengaruh perlakuan terhadap konversi ransum selama percobaan disajikan pada Tabel 4. Konversi ransum pada perlakuan temperatur air $25^{\circ}-27^{\circ} \mathrm{C}$ (T0) lebih tinggi dibandingkan dengan konversi ransum temperatur air $21^{\circ}-23^{\circ} \mathrm{C}$ (T1) sedangkan pada perlakuan waktu konversi ransum terendah (terbaik) yaitu pada perlakuan pengurangan waktu pemberian 2 jam, dan konversi ransum tertinggi (terburuk) diperoleh pada perlakuan pengurangan waktu 5 jam/hari. Hasil analisis ragam pengaruh perlakuan memberi pengaruh yang nyata $(\mathrm{P}<0,05)$ terhadap konversi ransum. 
Tabel 4. Konversi ransum selama percobaan pada perlakuan pengurangan waktu pemberian dan perbedaan temperatur air minum

\begin{tabular}{|c|c|c|c|c|c|c|}
\hline \multirow{2}{*}{$\begin{array}{l}\text { Faktor } \\
\text { Temperatur }\end{array}$} & \multicolumn{5}{|c|}{ Faktor waktu } & \multirow[t]{2}{*}{ Rata-rata } \\
\hline & W0 & W1 & W2 & W3 & W4 & \\
\hline T0 & $3,14^{\mathrm{a}}$ & $3,21^{\mathrm{a}}$ & $3,26^{\mathrm{a}}$ & $3,21^{a}$ & $3,43^{\mathrm{a}}$ & 3,25 \\
\hline $\mathrm{T} 1$ & $3,19^{\mathrm{ab}}$ & $3,03^{\mathrm{a}}$ & $3,07^{\mathrm{a}}$ & $3,15^{\mathrm{ab}}$ & $3,22^{b}$ & 3,13 \\
\hline Rata-rata & 3,17 & 3,17 & 3,17 & 3,18 & 3,33 & \\
\hline
\end{tabular}

Konversi ransum juga dipengaruhi oleh temperatur air minum $(\mathrm{P}<0,05)$. Pada percobaan ini konversi ransum sangat dipengaruhi oleh rataan pertambahan bobot badan yang dicapai, karena konsumsi ransum tidak menunjukkan perbedaan yang nyata. Perlakuan yang mencapai pertambahan berat badan tertinggi menghasilkan konversi ransum terbaik karena pertumbuhan mempengaruhi konversi ransum (Card dan Nesheim, 1979).

\section{KESIMPULAN}

Terdapat interaksi antara pemberian waktu pemberian dengan temperatur air minum yang berbeda terhadap pertambahan berat badan dan konversi ransum; pengaruh pengurangan waktu pemberian air minum 2 jam/hari dengan temperatur air $21-23^{\circ} \mathrm{C}$ menghasilkan performan paling baik pada ayam petelur periode grower.

\section{DAFTAR PUSTAKA}

Anggorodi, R. 1985. Kemajuan Mutakhir dalam Ilmu Makanan Ternak Unggas. Universitas Indonesia Press. Jakarta.

Anonimous. 1993. Commercial Layer Management Guide. Isa Brown, Quintin.

Anonimous. 2002. Commercial Layer Management Guide. Lohmann, Jakarta.

Card, L. E. dan M. C. Nesheim. 1979. Poultry Production. $12^{\text {th }}$ Ed. Lea and Febiger, Philadelphia.

Cresswell, D., dan P.S. Hardjoworo. 1977. Buletin Bimas Ayam. Direktorat Jenderal Peternakan. Jakarta.

Swick, R. A. 1999. Water Quality and Management for Poultry. American Soybean Association, Singapore.

Wahju, J. 1985. Kebutuhan Zat-zat Makanan untuk Unggas. Cetakan ketiga. Fakultas Peternakan, Institut Pertanian Bogor, Bogor. 